\title{
REVIEW
}

\section{Michael Cart's Top 200 Adult Books for Young Adults: Two Decades in Review}

\author{
TERRI SUICO \\ SAINT MARY'S COLLEGE
}

Considering the incredible growth in young adult literature between the 1996 and the 2016 editions of Young Adult Literature: From Romance to Realism, it was inevitable that parts from the first edition be excised in order to make room for an examination of the changes and advances made during those 30 years. One element that had to go was the literary analysis found in the original edition, something that Cart admitted he misses. While this is an understandable choice, it means that readers of later editions do not get to experience the full breadth of Cart's astute commentary and exploration of different works. Given his years of evaluating adult and young adult books for various Young Adult Library Association awards and Booklist magazine, he has a great of insight and knowledge to offer here. Consequently, Cart's 200 Top Adult Books for Young Adults: Two Decades in Review makes a viable companion to 2016's Young Adult Literature: From Romance to Realism.

The book's title provides an honest if incomplete picture of its contents. While the book does include a collection of adult books selected by Cart, it goes beyond mere synopses. Instead, it also delves into a thoughtful if pithy explanation of the books' appeal for young adults as well as the works' literary merits. Although a collection of relatively short reviews (each is one to two paragraphs) cannot completely replace lengthier and more extensive analysis and criticism, Cart compresses a lot of information and acumen into a confined space. The result is a helpful guide for those in search of adult books for teens and a valuable resource for teachers and scholars of young adult literature as they consider the crossover phenomenon and the potential for overlap between young adult and adult literature. 
The main portion of the book is divided into fiction and nonfiction, with the entries arranged alphabetically according to title. There is an edge given to fictional works, with approximately $60 \%$ of the 200 titles being categorized as fiction. For each book, Cart includes the categories, such as general fiction, graphic novel, poetry, or romance, in which the book belongs. Furthermore, Cart notes which books received the Young Adult Library Services Association's Alex Award, a distinction "given to ten books written for adults that have special appeal to young adults, ages 12 through 18” (“Alex Awards,” n.d.). The included titles range from the popular and expected, such as Jodi Picoult's still timely Nineteen Minutes and Malcolm Gladwell's The Tipping Point, to lesserknown surprises like Eleanor Catton's The Rehearsal. As per the title, Cart limits himself to 200 books that were published between 1990 and 2011, though he nimbly circumvents this by including recommendations to other, sometimes older, works that are by the same author, address similar topics, or have styles like the book in question. This approach also allows Cart to showcase his formidable knowledge of books, as he makes connections between the texts. For instance, the entry for Junot Diaz's 2007 work The Brief Wondrous Life of Oscar Wao includes a recommendation for Julia Alvarez's In the Time of the Butterflies for readers who want another book that examines the same historical events. The entry also mentions Diaz's earlier collection of short stories, Drown. The result is the giddy excitement of being in the presence of a knowledgeable and enthusiastic bibliophile who wants nothing more than to help you find just the right book for your interests, tastes, and personality.

The book has obvious worth for librarians and secondary teachers who are searching for titles to help their patrons or students make the leap from young adult to adult books. Cart's recommendations take into consideration different genres, topics, and forms, which speaks to a wide range of reading tastes. Additionally, the titles do not seem dated. I first approached the list with some trepidation, since the book was published in 2013 and focused on books from the previous two decades. Fortunately, the mix of modern classics such as Tim O'Brien's The Things They Carried and Margane Satrapi's Persepolis and gems that might not be at the forefront of the mind like Bill Wright's Sunday You Learn How to Boxkeep the list fresh and, in many cases, unexpected.

While the value for young adult teachers and scholars initially seems less obvious, Cart's Top 200 Adult Books for Young Adults: Two Decades in Review proves an important resource for these stakeholders. Besides offering Cart's wealth of insight in terms of what makes a book meaningful and appealing to young adults, regardless of the book's designation, it also adds to the ongoing 
conversation on what determines whether a book is considered young adult or adult literature. As noted in author Margot Rabb’s 2008 piece, "I'm Y.A. and I'm O.K.," the line between young adult and adult books is often a blurry one. The piece includes Cart's thoughts on this, as he states, "These days, what makes a book Y.A. is not so much what makes it as who makes it - and the 'who' is the marketing department" (Rabb, 2008, para 4). Cart reiterates this stance in the introduction for this book:

That these books have multigenerational appeal invites the question, who decides if they are to be published as adult or as young adult? The answer, increasingly, is the publisher's sales and marketing department, often in consultation with the Brobdingnagian bookseller Barnes \& Noble. Thus the final decision is made on the basis of not the content of the book but, rather, its sales potential. Will it do better with adult or young adult buyers? (p.6)

Cart's thoughtful and eloquent analysis of the situation crystallizes an issue that has long dogged young adult literature, namely what the true difference is between adult and young adult books. He brings up the point several times in the book summaries and reviews, thus inviting readers to consider both the characteristics of young adult literature versus adult literature as well as the role that publishers have in choosing the designations. This is an undeniably intriguing and worthwhile topic for young adult scholars and students to explore, and Cart's work gives them a basis on which to build.

Although Cart's Top 200 Adult Books for Young Adults might not be the typical scholarly book on young adult literature that is usually reviewed for Study and Scrutiny, it nevertheless speaks to several topics vital to the study of young adult literature and adolescent literary development. If you, like me, miss Cart's gleeful commentary on books that graced the first edition of From Romance to Realism: 50 Years of Growth and Change in Young Adult Literature or if you simply need recommendations for adult books that appeal to young adults, this is an essential addition to your collection. 


\section{REFERENCES}

Cart, M. (2013). Cart's top 200 adult books for young adults: Two decades in review. Chicago, IL: American Library Association.

Rabb, M. (2008, July 20). I'm Y.A. and I'm O.K. The New York Times. Retrieved from http://www.nytimes.com/2008/07/20/books/review/Rabb-t.html.

Alex Awards. (n.d.). Retrieved from http://www.ala.org/yalsa/alex-awards

TERRI SUICO is an assistant professor of education at Saint Mary's College in Notre Dame,

Indiana. Her research focuses on depictions of gender in young adult literature. 